\title{
Pelatihan F\&B Service dalam Meningkatkan Kualitas Pelayanan terhadap Konsumen di Desa Wisata Bongan
}

\author{
Ni Nyoman Widani ${ }^{1}$, Billy Tanius ${ }^{2}$, I Gusti Ayu Ari Agustini ${ }^{3}$ \\ nyoman.widani@pib.ac.id ${ }^{1}$, billy.tanius@pib.ac.id², ari.agustini@pib.ac.id ${ }^{3}$ \\ 1,2,3Politeknik Internasional Bali
}

\section{Article History:}

Received: 20-10-2021

Revised: 12-01-2022

Accepted: 17-01-2022
Keywords: Bongan tourism village, Culinary, Gonda, F\&B Service

\begin{abstract}
Industrial Revolution 4.0 is a term that is already familiar to people in Indonesia. The development of technology and information occurs so quickly that it has a huge impact on the industrial world as well as human behavior. This behavior affects how the tourism industry players provide services to consumers who come to visit the tourist village of Bongan Tabanan - Bali. Bongan Village as a tourist village also has culinary products that use the main ingredients of the Gonda plant. Gonda plant itself is known as one of the commodities that have economic value apart from rice plants. Ease in the cultivation process and lower operational value are an advantage for farmers compared to planting rice. Processed products from the gonda plant are offered directly when tourists come to visit the tourist village of Bongan. To achieve tourist satisfaction and increase purchases of Gonda processed products, culinary actors must be able to provide services or services that are managed professionally so as to provide satisfaction to customers or foreign tourists who visit. During the Covid19 pandemic, technological advances began to be used as F\&B services, one of which was using online media, such as Facebook, Instagram, Twitter and other websites. The purpose of Community Service Activities in Bongan Village is expected through F\&B Service Training to improve the quality of service to consumers in the tourist village of Bongan, Tabanan.
\end{abstract}

\section{Pendahuluan}

Bali adalah salah satu provinsi di Indonesia yang dikenal sebagai destinasi wisata domestik maupun internasional. Pulau Bali memiliki keindahan pengunungan, terasering sawah yang unik, pantai dengan terumbu karang yang unik dan cantik. Jenis wisata yang ditawarkan juga beranekaragam seperti wisata budaya, maritim, cagar alam, pertanian, spiritual (Subadra, 2021), konvensi, kuliner dan lain-lain. Wisata kuliner dijadikan salah satu daya tarik yang disajikan oleh setiap objek wisata yang ada di Bali. Selain wisatawan menikmati wisata, para wisatawan pun dikenalkan kuliner tradisional Bali yang kaya akan rempah dan proses pembuatannya yang unik dan juga ada kuliner yang sudah menyesuaikan dengan style internasional. Kuliner sebagai salah satu karakter dalam sektor pariwisata, disajikan dalam bentuk penawaran menu yang beranekaragam pula, dengan demikian diharapkan menjadi pasar yang pontensial dan mengundang investor untuk turut 
serta. Selain itu pula dengan menata wisata kuliner menjadi salah satu langkah pemerintah Bali dalam melestarikan dan memperkenalkan daya tarik kuliner nusantara khususnya kuliner tradisional Bali. Dampak positif yang ditimbulkan adalah meningkatnya perekonomian masyarakat khususnya pelaku usaha kuliner dan menjadi salah satu sumber peningkatan pendapatan asli daerah (PAD) melalui restribusi. Sebagai salah satu program dalam kegiatan PKM ini adalah mendukung usaha mikro, kecil dan menengah (UMKM) pada rantai nilai pariwisata agar dapat mempromosikan dan mengembangkan produk lokal yang berkelanjutan dengan prinsip perdagangan yang adil. Produk lokal tersebut antara lain adalah produk makanan, minuman, kerajinan,seni pertunjukan dan pertanian (PARIWISATA \& INDONESIA, 2016).

Saat ini berbagai menu atau produk lokal kuliner tradisional Bali banyak diangkat oleh masyarakat pelaku usaha kuliner tradisional Bali khususnya, dengan tujuan menyajikan makanan yang sehat sekaligus melestarikan budaya warisan nenek moyang (Wuruk \& Mandra, 2021). Jenis kuliner yang ditawarkan mulai dari makanan utama, makanan selingan dan minuman tradisional masyarakat Bali. Kuliner tradisional dibuat dengan menggunakan bahan lokal dan dengan cara pengolahan yang beragam dan bervariasi, serta memiliki ciri khas daerah setempat. Kuliner tradisional/khas Bali yang secara harafiah sudah berkembang sejak masuknya Agama Hindu di Bali, telah menjadi makanan asli Bali, bukan saja untuk masyarakatnya, tetapi juga secara religius diperuntukkan bagi para Dewa-Dewi sesuai kepercayaan mereka (Hendrayana, 2018).

Salah satu kuliner tradisional Bali yang saat ini mulai banyak peminatnya adalah kuliner yang menjadikan Gonda sebagai bahan olahan dengan berbagai macam menu seperti Gonda Uyah Lengis, Urab Gonda, Pelecing Gonda, Kripiki Gonda dan lainnya. Selain kuliner Gonda, pokdarwis desa bongan juga saat ini mulai mengolah gonda sebagai teh yang berkhasiat untuk kesehatan. Tanaman gonda merupakan tanaman akuatik dengan ciri morfologi batang berongga menyerupai tanaman kangkung (Ipomaea aquatica) dan tergolong tumbuhan setahun. Umumnya tanaman Gonda tersebar pada wilayah yang memiliki ketinggian 1-300 m dpl dengan lingkungan tumbuh tanah berlumpur seperti lahan persawahan, saluran irigasi dan tepian sungai(Junarta, Gunadi, \& Pradnyawathi, 2016). Tanaman gonda atau dengan nama ilmiah Sphenoclea zeylanica Gaertn termasuk dalam keluarga Sphenocleaceae. Berdasarkan hasil penelitian ilmiah tanaman gonda mengandung zat aktif secara farmakologis dengan sifat antidiare. Sifat ini menegaskan penggunaan $\mathrm{C}$. zeylanica sebagai obat antidiare seperti yang diusulkan oleh Balian atau disebut juga tabib tradisional (Sini, Sinha, \& Rajasekaran, 2011). Gonda awalnya oleh petani di Bali dianggap sebagai gulma pada tanaman padi, mengetahui bahwa gonda bisa dijadikan bahan olahan sayur yang enak dan bergizi. 


\section{ADMA}

Gurnal Pengabdian dan Pemberdayaan Masyarakat

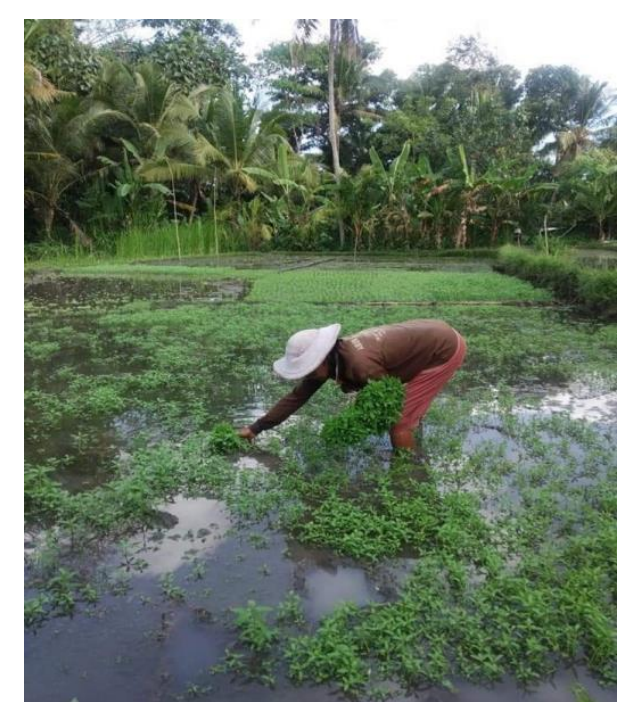

Gambar 1. Panen tanaman gonda sumber: dokumen PKM 2021

Banyak petani yang membudidayakan gonda di lahan sawah mereka, dikarenakan komoditas ekonomis yang mampu memberikan nilai tambah untuk petani dan budidaya tanaman gonda lebih mudah dan murah dibandingkan dengan tanaman padi (Elizabet, 2020). Sejalan dengan penjabaran diatas, bapak I Gede Sukadana, AP,SH,M.Si camat Kerambitan-Tabanan Bali, dalam wawancara dengan Bali TV menyatakan bahwa pemerintah kecamatan Kerambitan mendukung sector agrowisata di desa Timpag, karena memiliki potensi SDM dan potensi alam. Kegiatan agrowisata yang ditawarkan selain menikmati lanskap pertanian adalah memperkenalkan olahan tanaman Gonda sebagai kuliner khas desa Timpag.

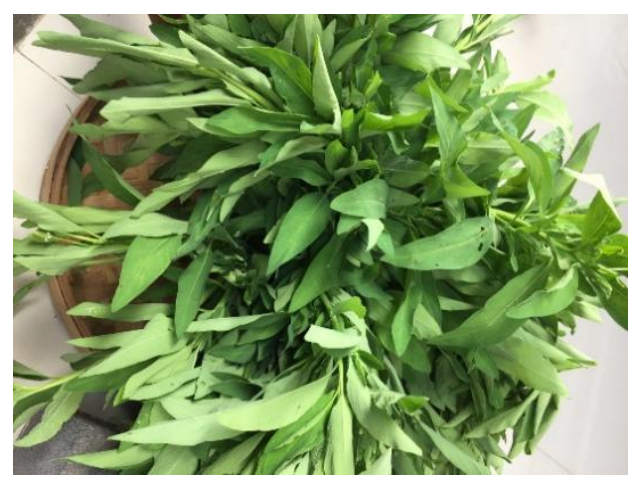

Gambar 2. Tanaman gonda sumber : dokumen PKM 2021

Pemerintah kecamatan Kerambitan turut membantu petani dalam Pengembangan pengelolaan tanaman Gonda dan proses pendistribusian Gonda. Salah satu konsumen tanaman Gonda desa Timpag adalah Desa Bongan Tabanan - Bali, yang turut mengembangkan produk olahan tanaman Gonda. Desa Bongan sebagai salah satu desa wisata, memiliki banyak potensi wisata yang dapat dikembangkan, juga turut 
memperkenalkan produk kuliner dan minuman kesehatan dari bahan olahan tanaman Gonda Produk ini dijadikan cinderamata bagi para wisatawan yang berkunjung ke desa wisata Bongan. Produk olahan yang saat ini sedang dikembangkan adalah kripik Gonda dan teh Gonda Bongan atau disingkat Teh GOBO. Teh GOBO adalah salah satu produk olahan masyarakat Bongan yang tergabung dalam Pokdarwis desa bongan. Dalam pengembangan produk teh GOBO, pokdarwis desa bongan mendapatkan dukungan pedampingan dari Politeknik Internasional Bali (PIB).

Produk olahan dari tanaman Gonda ditawarkan secara langsung ketika wisatawan datang berkunjung ke desa wisata Bongan. Untuk mencapai kepuasan wisatawan dan meningkatkan pembelian produk olahan tanaman gonda, pelaku kuliner harus mampu memberikan jasa service atau pelayanan yang dikelola secara professional sehingga memberikan kepuasan kepada pelanggan atau wisatawan asing yang berkunjung. Pelayanan penawaran kuliner atau disebut juga food and beverage service memiliki standar khusus dalam implementasinya. Praktek kegiatan F\&B service memiliki standar mulai dari menyajikan makanan dan minuman kepada para konsumen. Seorang food and beverage service selain bertugas untuk menjamin kualitas makanan dan minuman juga memiliki tugas dalam membuat Purchase Orders, Purchase Requesting, Menu Planning, membuat BEO, dan harus bisa berkomunikasi dengan baik untuk dapat mencapai kepuasan tamu (Desthiani, Suminar, \& Cristiani, 2021).

Bidang F\&B service saat ini mulai menerapkan konsep dengan memberikan pelayanan melalui penyajian berbasis teknologi, apalagi disaat pandemic Covid-19 saat ini. Bentuk pelayanan berbasis teknologi yang efisien dan praktis bertujuan untuk menarik pelanggan untuk datang berkunjung ke desa wisata Bongan dan menikmati produk olahan tanaman gonda yang di pasarkan. Teknologi yang digunakan F\&B service salah satunya dengan menggunakan media online, seperti Facebook, Instagram, twitter dan website lainnya. Dengan meningkatkannya kemampuan berkomunikasi para pelaku UMKM dalam bahasa Inggris diharapkan para pelaku UMKM mampu menyusun tulisan/konten mulai dari sejarah dari tanaman gonda, budidaya tanaman gonda, produk olahan tanaman Gonda, proses pembuatan produk olahan gonda dan lainnya.

PIB sebagai salah satu perguruan tinggi yang berada di daerah Tabanan, memiliki visi untuk "menjadi Perguruan Tinggi Vokasi yang berkualitas, berkarakter dan terpercaya" dalam menghasilkan SDM yang terbaik di industri pariwisata dan perhotelan. Saat ini mulai mendapatkan pengakuan dari pihak eksternal dalam eksistensi dan kualitasnya sebagai Tourismpreneurship campus(Politeknik Internasional Bali, 2017). PIB juga turut serta dalam mengembangkan dan meningkatkan potensi daerah sekitarnya sesuai kompentensi yang dimiliki. Program kegiatan yang dilakukan oleh PIB adalah menjadikan desa Bongan https://journal.universitasbumigora.ac.id/index.php/ADMA 
sebagai desa binaan. Latar belakang tersebut menjadi gagasan kami para dosen di lingkungan Politeknik Internasional Bali (PIB) untuk melakukan kegiatan Pengabdian kepada Masyarakat (PkM) di desa Bongan. Dalam usaha pengembangan dan peningkatan kualitas pelayanan terhadap konsumen dan memperkenalkan produk yang dikelola oleh pelaku UMKM yaitu dengan mengadakan Pelatihan F\&B Service dalam meningkatan kualitas pelayanan terhadap konsumen di desa wisata Bongan, Tabanan, Bali.

Kegiatan PKM ini dilaksanakan sebagai salah satu tugas dosen pada Tridharma Perguruan Tinggi adalah hal yang wajib dilaksanakan oleh setiap dosen ataupun mahasiswa. Tim pelaksana akan memberikan Pelatihan F\&B Service dalam meningkatan kualitas pelayanan para pelaku kuliner terhadap konsumen di desa wisata Bongan, Tabanan, Bali, sehingga konsumen yang berkunjung ke desa Bongan khususnya tamu asing akan merasa senang dengan pelayanan yang diberikan oleh para pelaku kuliner pada waktu menawarkan produk yang dijual, dan akan mau membeli produk yang ditawarkan (Widani, 2020). Pelatihan F\&B Service yang akan diberikan terkait dengan pelayanan yang baik yaitu pengetahuan dalam mendiskripsikan produk kuliner yang mereka tawarkan, mulai dari bahan olahan, bumbu dan proses pembuatannya. Pelaksanaan PKM berlangsung selama 1 hari yaitu pada hari Sabtu 18 September 2021. Selama pelaksanaan PKM, Tim pelaksana PIB akan berinteraksi aktif dalam melatih pelaku kuliner di Banjar Bongan Jawa, desa Bongan, Tabanan Bali. Luaran dari kegiatan Pengabdian Kepada Masyarakat berupa publikasi ilmiah di jurnal Nasional ber-ISSN (Pengabdian Masyarakat, 2020)

\section{Metode}

Pelaksanaan Pengabdian kepada Masyarakat yang merupakan salah satu dari Tri Dharma Perguruan Tinggi bagi dosen adalah bisa membantu masyarakat dengan membagikan ilmu yang dimiliki sehingga bisa meningkatkan kemampuan bagi para pelaku kuliner di desa Bongan dalam memberikan pelayanan yang baik kepada konsumen khususnya kepada wisatawan asing. Sebelum melakukan kegiatan dosen menyusun kegiatan berdasarkan kompetensi program studi dan dosen, dan di ajukan ke LPPM untuk di evaluasi apakah kegiatan yang diajukan layak untuk dilaksanaakan. Evaluasi dilakukan oleh LPPM dengan mempertimbangkan juga kebutuhan dari pengelola desa wisata atau Pokdarwis desa Bongan. Hasil evaluasi diumumkan oleh LPPM dalam rapat pimpinan dengan para kaprodi beserta Wakil direktur 1. Para dosen melakukan kegiatan Pengabdian kepada Masyarakat setelah mendapatkan surat tugas dari LPPM.

Metode yang akan digunakan tim pelaksana dalam melakukan Pengabdian kepada Masyarakat, yaitu dengan metode praktis yaitu praktek secara langung bagaimana melakukan komunikasi dengan konsumen. Materi atau modul akan diberikan sebagai panduan untuk memudahkan dalam melakukan interaksi, juga akan diberikan melalui 
presentasi (power point), contoh-contoh percakapan untuk bisa diperagakan Perlengkapan dan fasilitas yang akan disiapkan oleh tim pelaksana PkM Politeknik Internasional Bali dalam pelaksanaan proses Pelatihan F\&B Service dalam meningkatan kualitas pelayanan terhadap konsumen di desa wisata Bongan, Tabanan, Bali yaitu materi pelatihan/modul, alat tulis, dan menu. Modul yang dipersiapkan adalah modul English for Special Purposes yang memuat cara-cara memberikan pelayanan pada waktu menawarkan dan menjelaskan produk dari proses pembuatan produk olahan dan kuliner dari tanaman Gonda tersebut sampai cara penyajiannya. Berikut adalah susunan acara kegiatan pelatihan yang dilakukan pada tanggal 18 September 2021.

Tabel 1. Kegiatan PkM pelatihan $f \& b$ service dalam meningkatan kualitas pelayanan terhadap konsumen di Desa Wisata Bongan, Tabanan, Bali

\begin{tabular}{|c|c|c|c|c|}
\hline No & Hari & Waktu & Kegiatan & PIC \\
\hline \multirow[t]{3}{*}{1} & Sabtu & $09.00-12.00$ & $\begin{array}{ll}- & \text { Registrasi } \\
- & \text { Pembagian modul } \\
- & \text { Perkenalan / } \\
& \text { Pengarahan. }\end{array}$ & $\begin{array}{ll}- & \text { Vincent Reinaldy Biri } \\
- & \text { Komang Krisna Pramana } \\
& \text { Sarjana }\end{array}$ \\
\hline & & & $\begin{array}{l}\text { - Pelatihan F\&B } \\
\text { Service dalam } \\
\text { Meningkatan Kualitas } \\
\text { Pelayanan terhadap } \\
\text { Konsumen }\end{array}$ & $\begin{array}{ll}- & \text { Ni Nyoman Widani, S.S., } \\
& \text { M.Hum. } \\
-\quad & \text { I Gusti Ayu Ari Agustini, } \\
& \text { S.ST.Par., M.M. } \\
- & \text { Billy Tanius, S.ST.Par.,M.Par }\end{array}$ \\
\hline & & & $\begin{array}{ll}- & \text { Lunch time } \\
\text { - } & \text { Dokumentasi }\end{array}$ & $\begin{array}{l}\text { - } \quad \text { Vincent Reinaldy Biri } \\
-\quad \text { Komang Krisna Pramana } \\
\text { Sarjana }\end{array}$ \\
\hline
\end{tabular}

Masyarakat yang di sasar adalah masyarakat binan yang tergabung dalam pelaku Kuliner di desa Bongan, sejumlah yang diperlukan dalam satu kelompok yaitu 10 orang yang memiliki minat dan berkomitmen untuk mengikuti pelatihan ini. Pelatihan F\&B Service dilakukan dengan tetap memperhatikan dan melaksanakan protokes covid-19.

\section{Pembahasan}

Kegiatan yang di lakukan pada Pengabdian kepada Masyarakat (PkM) adalah pelatihan F\&B Service dalam meningkatkan kualitas pelayanan terhadap konsumen di Desa Bongan, Tabanan, Bali. Aktivitas awal yang dilakukan berkaitannya dengan pelatihan $F \& B$ Service dalam meningkatkan kualitas pelayanan terhadap konsumen di Desa Bongan, Tabanan, Bali, adalah sebagai berikut : 


\section{ADMA}

Jurnal Pengabdian dan Pemberdayaan Masyarakat
2022, Vol.2, No.2, pp.157-168

Doi: 10.30812/adma.v2i2.1528

Tabel 2. Uraian Kegiatan survey lokasi PkM pelatihan $f \& b$ service dalam meningkatan kualitas pelayanan terhadap konsumen di Desa Wisata Bongan, Tabanan, Bali

\begin{tabular}{cc}
\hline No. & \multicolumn{1}{c}{ Uraian Kegiatan } \\
\hline 1. & Sabtu 17 April 2021 \\
& $(11: 00-14: 00)$ \\
& Survey lokasi Kegiatan PkM Di Warga \\
& Binaan: Ibu Ida Ayu Fajar, di Banjar \\
& Bongan Jawa Kawan
\end{tabular}

2. Survey lokasi Kegiatan PkM Di Warga Binaan Bapak I Nengah Makir, di Banjar Bongan Jawa Kawan

3. Mengikuti Proses pembuatan Keripik Gonda di lokasi warga binaan di Rumah Ibu Ida Ayu Fajar, di Banjar Bongan Jawa Kawan

4. Sabtu 15 Mei 2021

Mengunjungi lokasi stand penjualan Teh GOBO di Gerembengan Desa Bonagn

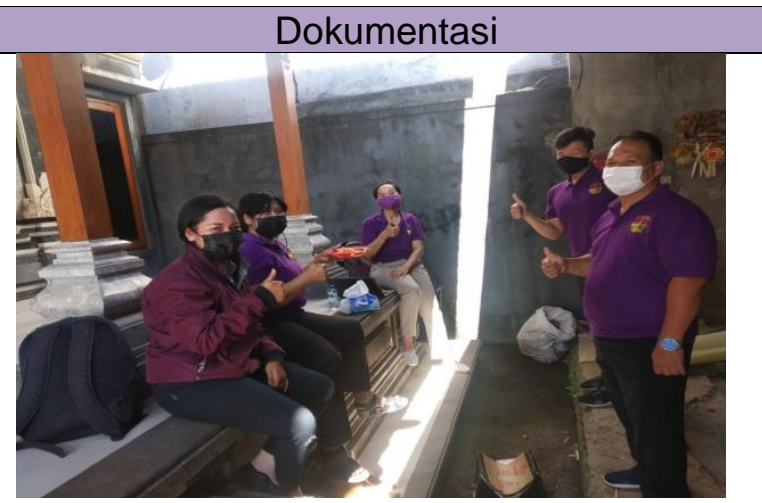

Gambar 3. Lokasi Rumah Ibu Ida Ayu Fajar

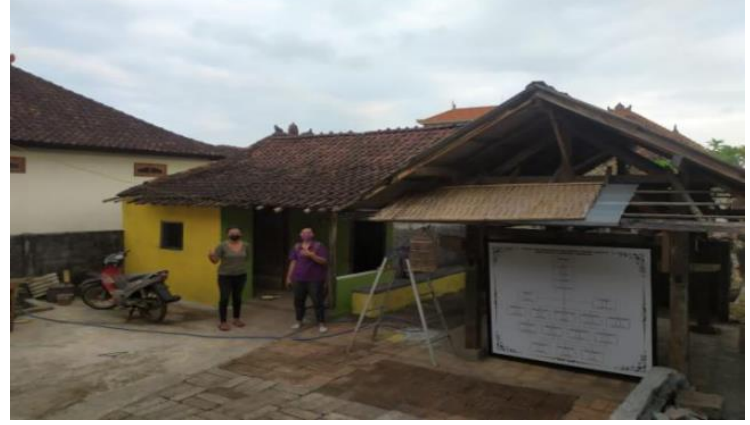

Gambar 4. Lokasi Rumah Bpk I Nengah Makir

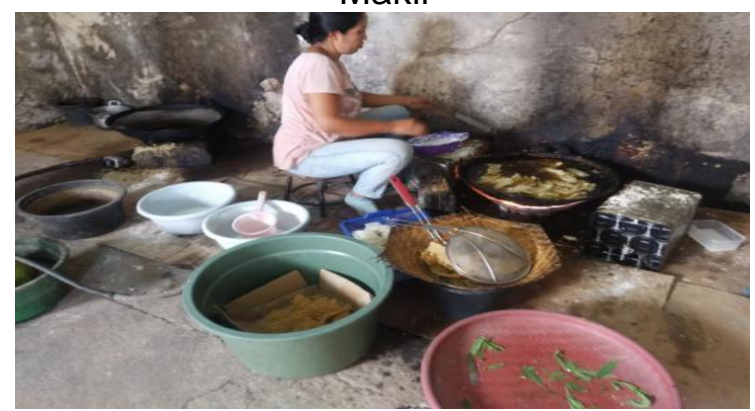

Gambar 5. Proses pembuatan Keripik Gonda

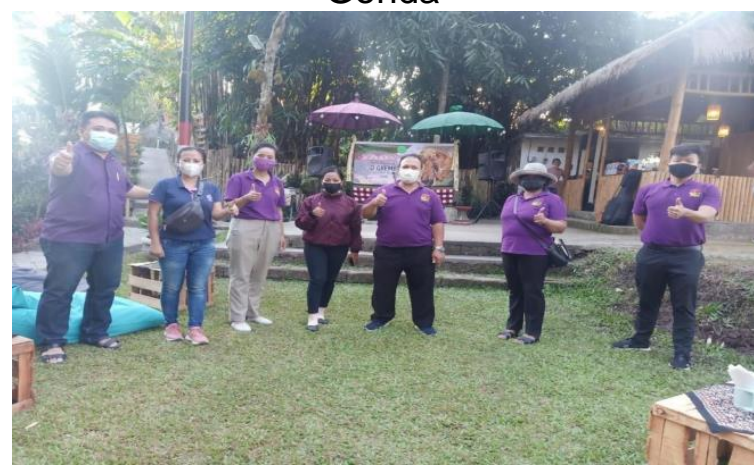

Gambar 6. Lokasi objek wisata Grembengan 


\section{ADMA}

Gurnal Pengabdian dan Pemberdayaan Masyarakat
2022, Vol.2, No.2, pp.157-168

Doi: 10.30812/adma.v2i2.1528

Selanjutnya melakukan sosialisasi pelatihan F\&B Service di Rumah Warga Binaan sampai pada Serah Terima Peralatan dan Perlengkapan Penunjang kegiatan produksi Teh Gonda dan Keripik Gonda di lokasi rumah warga binaan Di Banjar Bongan Jawa Kawan :

Tabel 3. Uraian Kegiatan sosialisasi pelatihan $f \& b$ service dalam meningkatan kualitas pelayanan terhadap konsumen di Desa Wisata Bongan, Tabanan, Bali

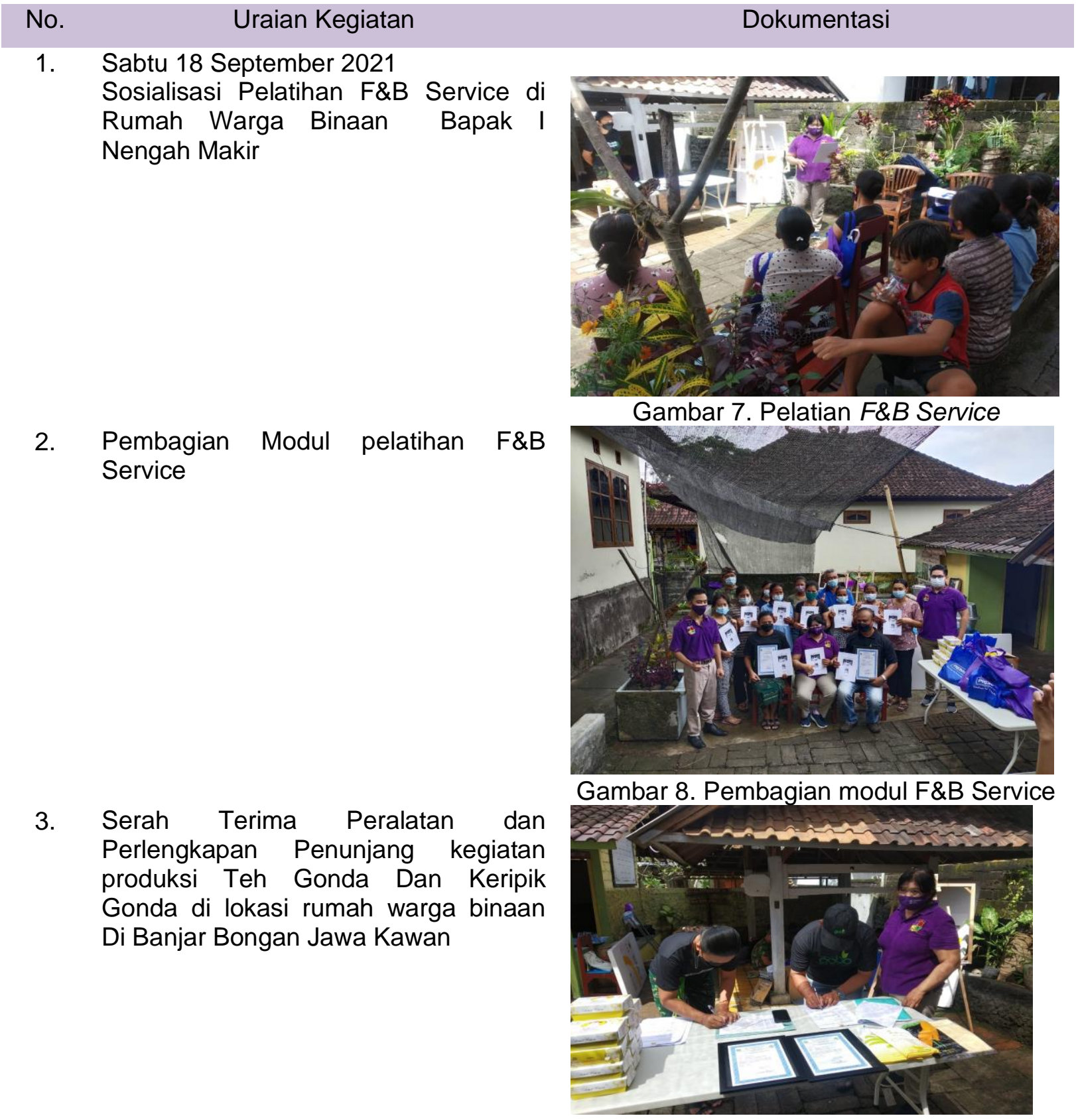

Gambar 9. Penandatanganan serah Terima peralatan dan perlengkapan PkM 
ADMA

Gurnal Pengabdian dan Pemberdayaan Masyarakat
2022, Vol.2, No.2, pp.157-168

Doi: $10.30812 / a d m a . v 2 i 2.1528$

Berikutnya sebagai evaluasi dari kegiatan pengabdian yang telah dilaksanakan dengan peserta warga binaan UMKM Banjar Bongan Jawa Kawan yang diberikan pelatihan F\&B Service dalam meningkatkan kualitas pelayanan terhadap konsumen :

Tabel 4. Evaluasi pelatihan $f \& b$ service dalam meningkatan kualitas pelayanan terhadap konsumen di Desa Wisata Bongan, Tabanan, Bali

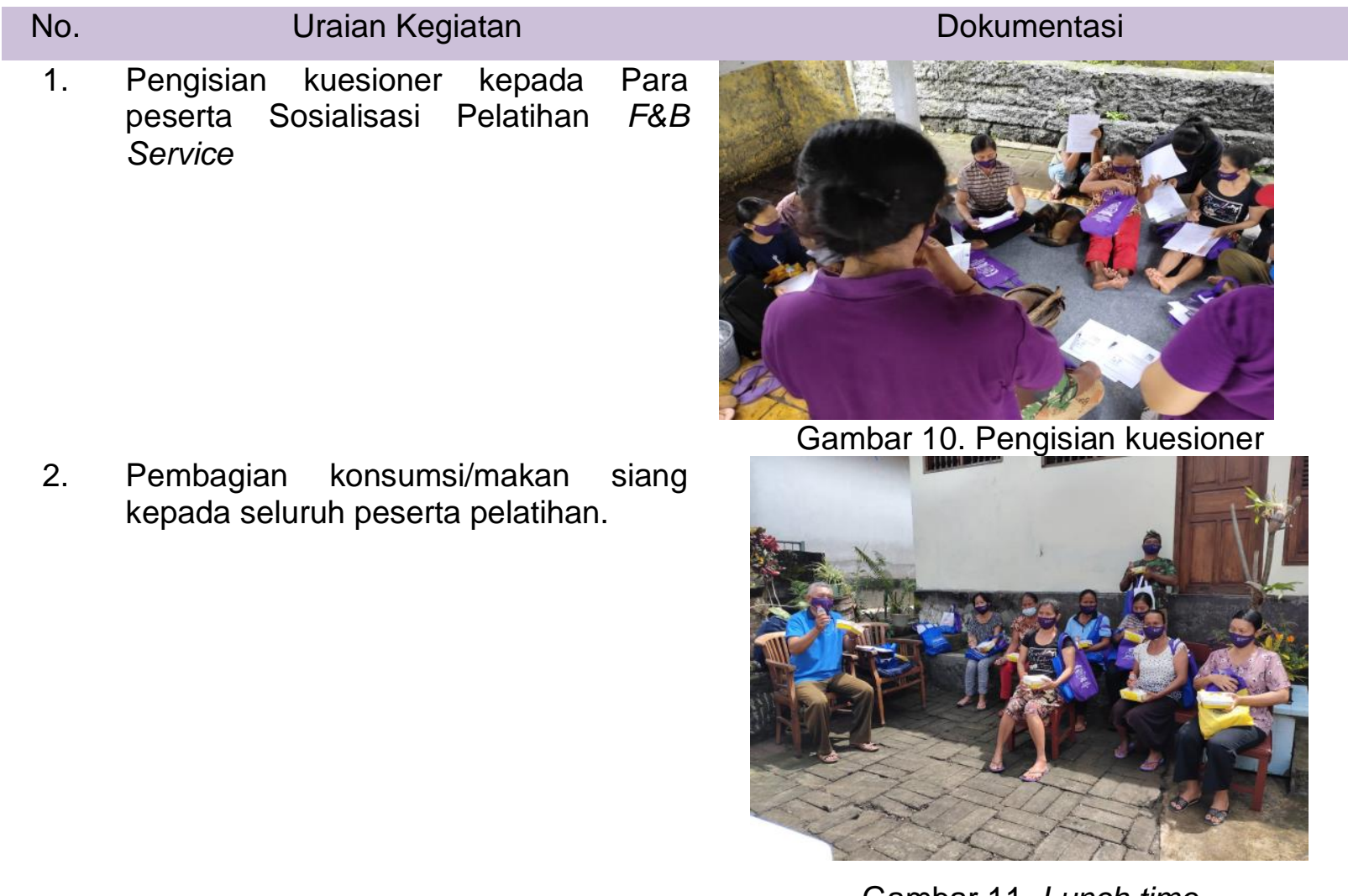

Gambar 11. Lunch time

Adapun hasil dari pelaksanaan kegiatan PkM tentang pelatihan F\&B Service dalam meningkatkan kualitas pelayanan terhadap konsumen di Desa Bongan, Tabanan, Bali yaitu:

1. Peserta yang hadir berjumah 11 orang yang merupakan warga binaan UMKM Banjar Bongan Jawa Kawan yang diberikan pelatihan F\&B Service dalam meningkatkan kualitas pelayanan terhadap konsumen.

2. Pada acara sosialisasi tersebut peserta diberikan souvenir bag PIB yang berisikan masker dan alat tulis juga dibagikan modul pelatihan F\&B Service dalam meningkatkan kualitas pelayanan terhadap konsumen kepada setiap warga binaan sebagai bahan/materi pelatihan yang berisikan contoh-contoh percakapan dalam melakukan komunikasi sebagai pedoman bagi peserta ketika berinteraksi dengan wisatawan asing.

3. Peserta pelatihan diberikan modul tentang pelatihan F\&B Service dalam meningkatkan kualitas pelayanan terhadap konsumen yaitu dari cara mendiskripsikan produk (Describing Product). Cara menjelaskan proses produksi (Cooking Proces), cara 
menjelaskan manfaat produk (Benefit of Product) dan cara menawarkan produk (Offering Product) dalam bahasa Inggris.

4. Metode yang digunakan dalam pelaksanaan pelatihan F\&B Service yaitu dengan metode praktis yaitu praktek secara langung ketika melakukan komunikasi dengan konsumen. Materi atau modul yang diberikan sebagai panduan untuk memudahkan dalam melakukan interaksi. Contoh-contoh percakapan diberikan untuk bisa dipraktekan secara langsung. Para peserta dilatih secara langsung untuk mampu menggunkana bahasa Inggris ketika berintenraksi dengan konsumen, khususnya dengan wisatawan asing dengan cara melakukan praktek langsung dalam penjualan produk.

5. Kuesioner disebar/diberikan di akhir pelatihan untuk mengetahui tanggapan peserta/warga masyarakat terkait denggan pelatihan F\&B Service ini. Respon dari peserta menyatakan :

a) Puas dengan kegiatan PkM yang dilakasanakan oleh PIB.

b) Kegiatan yang dilaksanakan sesuai dengan kebutuhan pelaku kuliner yang ada di desa Bongan.

c) Peserta kegiatan menyatakan kesediaannya jika ada kegiatan serupa diselenggarakan kembali.

\section{Kesimpulan}

Pelatihan F\&B Service dalam meningkatan kualitas pelayanan terhadap konsumen di desa wisata Bongan, Tabanan, Bali ini dilakukan untuk mendukung upaya peningkatan kualitas pelayanan dalam penjualan produk kuliner tanaman Gonda, ketika berinteraksi dengan para konsumen khususnya wisatawan asing yang datang berkunjung ke Desa Bongan. Pelatihan ini dilakukan dengan penerapan model pembelajaran English for Special Purpose yang sederhana dan praktis. Praktek langsung percakapan singkat antara warga binaan dengan konsumen (wisatawan asing), sehingga para peserta pelatihan dapat memahami materi yang disampaikan dan dengan menciptakan situati pelatihan yang menyenangkan serta guna meningkatkan pembendaharaan kosakata bahasa Inggris peserta pelatihan dengan cepat dan praktis.

Pelatihan dapat berjalan dengan lacar, para peserta binaan merasa sangat senang dan berperan aktif dalam pelatihan, interaktif dilakukan secara inten karena pada dasarnya kebanyakan dari peserta adalah para petani yang lebih banyak bergelut dengan pekerjaannya di sawah, sehingga perlu pelatihan yang extra dan banyak memberikan praktek langsung, tetapi pada umumnya peserta sangat antusias dan mau berperan aktif dalam pelatihan yang berlangsung.

Dari hasil kuesioner yang disebar, dapat diketahui bahwa pada umumnya peserta pelatihan merasa sangat senang dengan pelatihan $F \& B$ service ini dan mengharapkan https://journal.universitasbumigora.ac.id/index.php/ADMA

E-ISSN: $2723-7370$ 
adanya kegiatan yang berkelanjutan dalam kegiatan pembinaan seperti ini, karena memberi manfaat yang sangat bagus untuk perkembangan dan pelayanan UMKM di desa Bongan kedepannya.

\section{Ucapan Terimakasih}

Terimakasih kepada Politeknik Internasional Bali yang telah membantu dan memberikan dukungan sehingga kegiatan pelatihan $F \& B$ service bagi masyarakat desa Bongan dapat terlaksana dan berjalan dengan lancar. Selain itu juga kami ucapkan terimakasih kepada Pokdarwis dan Masyarakat Desa wisata Bongan, Tabanan - Bali yang berpartisipasi aktif sehingga kegiatan ini dapat terwujud.

\section{Daftar Pustaka}

Desthiani, U., Suminar, R., \& Cristiani, S. (2021). Peran dan Tugas Administrasi Food \& Beverage Service Pada Hotel Santika Bsd City Serpong. In Peningkatan Kompetensi Mahasiswa Melalui Program Vokasi untuk Memenuhi Kebutuhan Dunia Industri (pp. 2838). Retrieved from http://openjournal.unpam.ac.id/

Elizabet, P. S. (2020). Balai Pengkajian Teknologi Pertanian BALI (/ ind) Gonda Timpag Sumber Daya Genetik dari Tabanan. Bali. Retrieved from https://bali.litbang.pertanian.go.id/ind/index.php/info-teknologi/1104-gonda-timpag-sumberdaya-genetik-dari-tabanan

Hendrayana, M. (2018). Strategi pengembangan makanan tradisional bali di hotel area sanurdenpasar. Jurnal Hospitality Management, 2(2). Retrieved from https://jihm.stpbipress.id/index.php/JIHM/article/download/72/70/

Junarta, I. W., Gunadi, I. G. A., \& Pradnyawathi, N. L. M. (2016). E-Jurnal Agroekoteknologi Tropika. E-Jurnal Agroekoteknologi Tropika, 5(1), 275-283. Retrieved from https://ojs.unud.ac.id/index.php/JAT/article/view/22420

PARIWISATA, M., \& INDONESIA, R. (2016). Peraturan Menteri Pariwisata Republik Indonesia Nomor 14 Tahun 2016 Tentang Pedoman Destinasi Pariwisata Berkelanjutan.

Pengabdian Masyarakat, D. R. dan. (2020). Panduan Penelitian dan Pengabdian Kepada Masyarakat Edisi XIII. Retrieved from https://dikti.kemdikbud.go.id/penelitian/

Politeknik Internasional Bali. (2017). Panduan Pengabdian Masyarakat Politeknik Internasional Bali Tahun 2017. Bali.

Sini, K. R., Sinha, B. N., \& Rajasekaran, A. (2011). Antidiarrheal activity of Capparis zeylanica leaf extracts. Journal of Advanced Pharmaceutical Technology and Research, 2(1), 39-42. https://doi.org/10.4103/2231-4040.79803 


\section{ADMA}

Durnal Pengabdian dan Pemberdayaan Masyarakat
2022, Vol.2, No.2, pp.157-168

Doi: 10.30812/adma.v2i2.1528

Subadra, I. N. (2021). Pariwisata Budaya dan Pandemi Covid-19: Memahami Kebijakan Pemerintah dan Reaksi Masyarakat Bali. Jurnal Kajian Bali (Journal of Bali Studies), 11(1), 1. https://doi.org/10.24843/jkb.2021.v11.i01.p01

Widani, N. N. (2020). English For Food and Beverage Services. Bali: Politeknik Internasional Bali.

Wuruk, H., \& Mandra, D. M. (2021). Pengusaha Kuliner Bali Tetap Lestarikan Kuliner Khas Bali. Bisniswisata.Co.ld, pp. 1-2. Retrieved from https://bisniswisata.co.id/pengusaha-kulinerbali-tetap-lestarikan-kuliner-khas-bali/ 